\title{
PENENTUAN KADAR VITAMIN C PADA MANGGA KWENI \\ DENGAN MENGGUNAKAN METODE IODOMETRI
}

\section{Uswatun Hasanah*}

Surel: uswatun.hasanah241@gmail.com

\begin{abstract}
Vitamin $C$ is one of the nutrients that role as antioxidant and effectively overcome the free radicals that can damage cells or tissue. Fruit is a good source of vitamin $C$, such as the mango kweni fruit. This study aimed to determine the levels of vitamin $C$ in the mango kweni fruit using Iodimetry method. The results of the analysis of vitamin $C$ in the mango kweni by using Iodimetry average was $3.48 \mathrm{~g} / 100 \mathrm{~g}$.
\end{abstract}

Keywords: Vitamin C, Manggo kweni, Iodimetry.

\section{PENDAHULUAN}

* Dra.Uswatun Hasanah,M.Si. Dosen Jurusan Biologi FMIPA Unimed. 
$\mathbf{V}$ itamin C adalah zat organik yang dibutuhkan oleh tubuh manusia dalam jumlah kecil, untuk memelihara fungsi metabolisme. Vitamin ini sangat diperlukan oleh manusia. (Martin,1981). Vitamin C tidak dapat disintesis di dalam tubuh manusia, sehingga diperlukan vitamin $\mathrm{C}$ dari luar tubuh. Vitamin $\mathrm{C}$ sering terdapat bersama dengan zat-zat atau vitamin-vitamin lainnya di dalam makanan. Bahan makanan yang mengandung vitamin $\mathrm{C}$ paling utama adalah buah-buahan dan sayuran. Vitamin $\mathrm{C}$ merupakan vitamin yang larut dalam air, memiliki peranan penting dalam perbaikan jaringan tubuh dan proses metabolisme tubuh melalui reaksi oksidasi dan reduksi. Vitamin $\mathrm{C}$ juga berperan sebagai antioksidan, mempercepat penyembuhan luka, proses hidroksilasi hormon koteks adrenal, pembentukan kolagen dan menurunkan kadar kolesterol di dalam darah. Fungsi Vitamin C dalam tubuh adalah untuk membentuk kolagen interselluler guna menyempurnakan tulang dan gigi, mencegah bisul dan pendarahan. Vitamin $\mathrm{C}$ berperan sebagai antioksidan yang kuat yang dapat melindungi sel dari agen-agen penyebab kanker, dan secara khusus mampu meningkatkan daya serap tubuh atas kalsium (mineral untuk pertumbuhan gigi dan tulang) serta zat besi dari bahan makanan lain (Godam, 2006). Naidu (2003) menyatakan bahwa vitamin $\mathrm{C}$ merupakan vitamin yang larut dalam air dan esensial untuk biosintesis kolagen.

Kekurangan Vitamin C menyebab-kan sariawan, gusi dan kulit mudah berdarah, sendi-sendi sakit dan luka sembuhnya lama (Harper., et.al,1986). Beberapa tanda kekurangan vitamin $\mathrm{C}$ di dalam tubuh adalah :Rambut sangat kering dan bercabang, Kulit bersisik, kering, dan kasar, Gusi mudah berdarah dan meradang, Luka lambat sembuh, mengalami infeksi berulang, dan mudah berdarah, Mengalami mimisan (epistaksis) berulang, Nyeri atau pembengkakan pada sendi, Anemia, Gigi mudah keropos.

Vitamin $\mathrm{C}$ adalah salah satu zat gizi yang berperan sebagai antioksidan dan efektif mengatasi radikal bebas yang dapat merusak sel atau jaringan, termasuk melindungi lensa dari kerusakan oksidatif yang ditimbulkan oleh radiasi. Vitamin $\mathrm{C}$ juga dapat mengurangi resiko kanker dan mengurangi kerusakan akibat radikal bebas yang dapat memicu kanker (Taylor, 1993).

Status vitamin $\mathrm{C}$ seseorang sangat tergantung dari usia, jenis kelamin, asupan vitamin C harian, kemampuan absorpsi dan ekskresi, serta adanya penyakit tertentu (Schetman, 1989). Rendahnya asupan serat dapat mempengaruhi asupan vitamin $\mathrm{C}$ karena bahan makanan sumber serat dan buah-buahan juga merupakan sumber vitamin C (Narins, 1996). Kebutuhan Vitamin C setiap hari untuk manusia tergantung pada umur,yaitu $30 \mathrm{mg}$ untuk bayi yang berumur kurang dari satu tahun, $35 \mathrm{mg}$ untuk bayi berumur 1-3 tahun, $50 \mathrm{mg}$ untuk anak-anak berumur 4-6 tahun, 60 mg untuk anak-anak berumur 7-12 tahun, $100 \mathrm{mg}$ untuk wanita hamil dan $150 \mathrm{mg}$ untuk wanita menyusui (Harvey, 1980). 


\section{METODE PENELITIAN}

\section{Waktu dan Tempat}

Penelitian dilakukan mulai awal

bulan September sampai dengan akhir bulan November 2017. Penelitian ini dilakukan di laboratorium Biokimia Jurusan Biologi FMIPA Unimed.

\section{Alat dan Bahan}

Bahan kimia yang digunakan untuk titrasi iodometri meliputi kalium iodide $\left(\mathrm{KIO}_{3}\right)$, iodine $\left(\mathrm{I}_{2}\right)$, asam sulfat pekat $\left(\mathrm{H}_{2} \mathrm{SO}_{4}\right)$, kalium iodat (KI), natrium tiosulfat $\left(\mathrm{Na}_{2} \mathrm{~S}_{2} \mathrm{O}_{3}\right)$, amilum, aquades dan aquabides. Bahan utama yang digunakan dalam penelitian ini adalah mangga kweni yang dipetik dari pohon kweni yang tumbuh di halaman rumah peneliti. Alat-alat yang digunakan dalam penelitian ini terdiri atas: alat-alat gelas, timbangan analitik, corong pendek, buret, blender, alumunium foil, kertas saring. Mangga kweni yang digunakan pada penelitian ini disajikan pada Gambar 1 berikut ini.

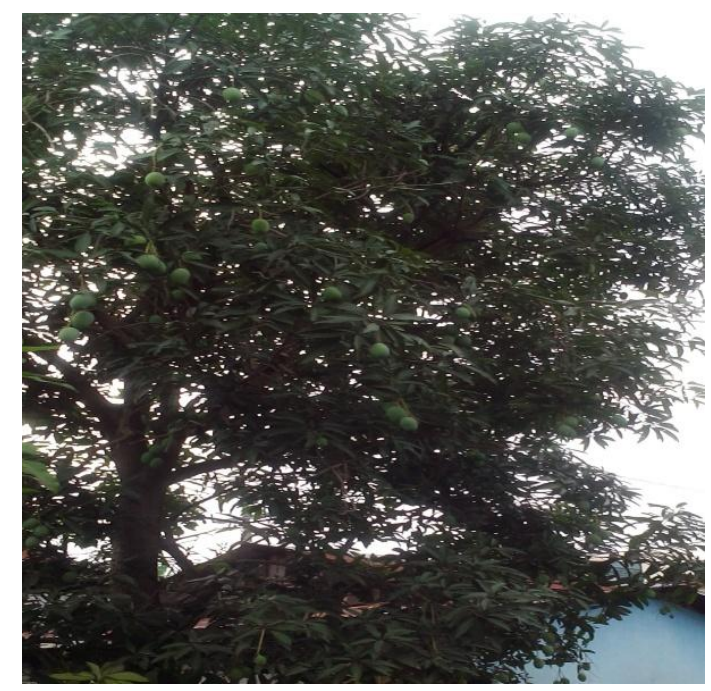

Gambar 1. Sampel buah mangga kweni di pohon

\section{Prosedur Kerja \\ Pembuatan larutan standar primer $\mathrm{KIO}_{3} 0,1 \mathrm{~N}$}

Ditimbang 0,3567 g kristal $\mathrm{KIO}_{3}$, dimasukkan dalam labu takar $100 \mathrm{~mL}$, kemudian ditambah aquabides sampai tanda batas lalu dihomogenkan. Pembuatan larutan standar Iodium $0,1 \mathrm{~N}$

Ditimbang 2,5 g kristal KI lalu dilarutkan dalam $25 \mathrm{~mL}$ aquabides. Kemudian ditimbang 12,7 g kristal I2 dan dimasukkan dalam larutan KI sedikit demi sedikit sampai semuanya larut (dimasukkan dalam botol tertutup dan dikocok). Kemudian ditambahkan aquabides sampai $1000 \mathrm{~mL}$.

Pembuatan larutan $\mathrm{Na}_{2} \mathrm{~S}_{2} \mathrm{O}_{3} 0,1 \mathrm{~N}$

Ditimbang kira-kira 9,9268 g kristal $\mathrm{Na}_{2} \mathrm{~S}_{2} \mathrm{O}_{3}$ lalu dimasukkan ke dalam beaker glass. Setelah itu ditambahkan aquades $400 \mathrm{~mL}$ lalu diaduk sampai homogen

\section{Pembuatan larutan amilum 1\%}

Ditimbang $1 \mathrm{~g}$ amilum, lalu dilarutkan ke dalam $100 \mathrm{~mL}$ aquades.

\section{Pembuatan KI 10\%}

Ditimbang kristal kalium iodide sebanyak $50 \mathrm{~g}$, lalu dilarutkan dalam aquades sampai $500 \mathrm{~mL}$ kemudian dihomogenkan.

\section{Pembuatan larutan $\mathrm{H}_{2} \mathrm{SO}_{4} 10 \%$}

Ditimbang larutan $\quad \mathrm{H}_{2} \mathrm{SO}_{4}$ sebanyak 1,031 mL, lalu dimasukkan ke dalam beaker glass dan tambahkan sebanyak $100 \mathrm{~mL}$ aquabides.

\section{Standarisasi larutan $\mathrm{Na}_{2} \mathrm{~S}_{2} \mathrm{O}_{3}$ dengan larutan $\mathrm{KIO}_{3} \mathrm{O}, 1 \mathrm{~N}$}

Dipipet 10 mL larutan $\mathrm{KIO}_{3}$ 0,1 $\mathrm{N}$, kemudian masukkan ke dalam erlenmeyer. Setelah itu, ditambahkan 5 mL larutan KI 10\%, lalu ditambahkan $2 \mathrm{~mL}$ larutan $\mathrm{H}_{2} \mathrm{SO}_{4}$ dan dititrasi dengan larutan $\mathrm{Na}_{2} \mathrm{~S}_{2} \mathrm{O}_{3}$ sampai 
berwarna kuning muda. Selanjutnya ditambahkan beberapa tetes larutan amilum 1\% lalu dititrasi dengan larutan $\mathrm{Na}_{2} \mathrm{~S}_{2} \mathrm{O}_{3}$ sampai warna biru hilang.

\section{Standarisasi larutan $I_{2}$ dengan} larutan standar $\mathrm{Na}_{2} \mathrm{~S}_{2} \mathrm{O}_{3} \mathrm{O}, 03 \mathrm{~N}$

Dipipet $10 \mathrm{~mL}$ larutan $\mathrm{I} 2$, lalu dititrasi dengan larutan $\mathrm{Na}_{2} \mathrm{~S}_{2} \mathrm{O}_{3}$ sampai warna kuning muda. Kemudian ditambahkan beberapa tetes larutan amilum, selanjutnya dititrasi dengan larutan $\mathrm{Na}_{2} \mathrm{~S}_{2} \mathrm{O}_{3}$ sampai warna birunya hilang.

\section{Penentuan Kadar Vitamin C Dengan Larutan Iodium Standar}

Sebelum mangga kweni dianalisa kadarvitamin C-nya, perlu dipersiapkan sampelsebagai berikut. Buah mangga kweni yangtelah dikupas diambil daging buahnya,kemudian diblender sampai homogen (terbentuk slurry). Ditimbang 20,00 gram slurry dimasukkan ke dalam labuukur $100 \mathrm{~mL}$ dan ditambahkan akuades sampaitanda batas kemudian dikocok sampaihomogen. Kemudian larutan disentrifuge dan disaring. Filtrat mangga kweni yang diperoleh siapuntuk dianalisa kadar vitamin Cnya.Sebanyak $10,00 \mathrm{~mL}$ filtrat buah mangga kweni dimasukkan ke dalam labu titrasi danditambahkan $2 \mathrm{~mL}$ larutan amilum $1 \%$ dan $20 \mathrm{~mL}$ akuades. Kemudian larutan tersebutdititrasi dengan larutan standar $\mathrm{I}_{2}$ 0,01Nsampai terbentuk warna biru tua yang tidakhilang selama 1 menit. Titrasi dilakukan 3 kali pengulangan. Kandungan vitamin $\mathrm{C}$ pada mangga kweni ditentukan dengan rumus : $1 \mathrm{~mL}$ $\mathrm{I}_{2}=0.88 \mathrm{mg}$ Vitamin C.

\section{HASIL DAN PEMBAHASAN}

Larutan sampel dititrasi dengan larutan iodium sampai larutan sampel berwarna biru. Warna biru yang dihasilkan merupakan iod-amilum yang menandakan bahwa proses titrasi telah mencapai titik akhir. Setelah dihitung, kadar vitamin $\mathrm{C}$ yang terdapat dalam larutan sampel mang- ga kweni dapat dilihat pada Tabel 1 berikut ini.

Tabel 1. Kadar vitamin C yang terdapat pada sampel mangga kweni

\begin{tabular}{|c|c|c|c|c|c|}
\hline & \multicolumn{3}{|c|}{$\begin{array}{c}\text { Kadar Vitamin C } \\
\text { (g/100g) }\end{array}$} & \\
\hline & \multicolumn{3}{|c|}{ Ulangan } & & \\
\hline No. & 1 & 2 & 3 & Jlh & $\begin{array}{c}\text { Rata- } \\
\text { rata }\end{array}$ \\
\hline 1 & 3.5 & 3.5 & 3.2 & 10.2 & 3.4 \\
\hline 2 & 3.7 & 3.9 & 3.8 & 11.4 & 3.8 \\
\hline 3 & 3.5 & 3.8 & 3.8 & 11.1 & 3.7 \\
\hline 4 & 3.1 & 3.0 & 3.0 & 9.1 & 3.03 \\
\hline Jlh & 13.8 & 14.2 & 13.8 & 41.8 & 13.93 \\
\hline $\begin{array}{c}\text { Rata- } \\
\text { rata }\end{array}$ & 3.45 & 3.55 & 3.45 & 10.45 & 3.48 \\
\hline
\end{tabular}

Dari Tabel 1 di atas dapat dilihat bahwa kadar vitamin $\mathrm{C}$ tertinggi terdapat dalam sampel nomor 2 ulangan ke 2 yaitu 3.9 g/100g. Sedangkan kadar vitamin $\mathrm{C}$ terendah terdapat pada sampel nomor 4 ulangan 2 dan ulangan 3 yaitu $3.0 \mathrm{~g} / 100 \mathrm{~g}$. Kadar vitamin $\mathrm{C}$ dalam buah mangga kweni rata-rata adalah $3.48 \mathrm{~g} / 100 \mathrm{~g}$.

Radikal bebasmerupakan penyebabkematian sel akibat teroksidasinya berbagai zat yang diperlukan untuk optimalisasi fungsi 
sel (Budiman, 2003). Radikal bebas banyak dikaitkan dengan berbagai penyakit degeneratif yang menurunkan kualitas hidup lansia Radikal bebas adalah atom ataumolekul yang memiliki satu atau lebih elektron yang tidak berpasangan, sehingga cenderung mendapat elektron dari zat lain menjadikan radikal bebas bersifat sangat reaktif (Murray.,et, al, 1996). Menurut Kooter (2004), radikal bebas dapat dihasilkan dari lingkungan luar tubuh (radiasi ultra violet, polutanudara, asaprokok) dan dari dalam tubuh (reaksi redoks enzimatis yang melibatkan oksigen pada metabolisme normal, proses fagositosis, $\mathrm{H}_{2} \mathrm{O}_{2}$ yang dengan adanya $\mathrm{Fe}$ dan $\mathrm{Cu}$ menghasilkan radikal hidroksil). Kerusakan-kerusakan yang dapat ditimbulkan oleh radikal bebas ini adalah kerusakan membrane sel, kerusakan protein, kerusakan DNA, lipid peroksida, dan proses penuaan. Radikal bebas secara terus menerus diproduksi dalam eritrosit akibat tingginya tekanan $\mathrm{O}_{2}$ dan besi heme. Secara spontanhemoglobin akanmenghasilkan superoksida $\left(\mathrm{O}_{2}{ }^{-}\right)$. Proses reduksi tersebut diikuti proses oksidasihemoglobinmenjadi methemoglobin.

Effek negatif radikal bebas dapat dicegah oleh antioksidan, salah satunya adalah vitaminC. Vitamin C merupakan antioksidan pada larutan aqueous seperti darah dan di dalam sel(intraseluler). Pada faseaqueous, vitaminCakanbereaksi dengan radikal bebas sebelum mereka menginisiasi kerusakanterutama pada lipid seluler. Vitamin $\mathrm{C}$ bereaksi dengan berbagai macam spesies oksigen reaktif(ROS) dan spesies nitrogen yang ada dalam darah atau di dalam sel yaitu dengan mendonorkanelektronnya untuk radikal bebas tersebut. Beberapa radikal bebas dan spesies reaktif yang bereaksi dengan vitamin $\mathrm{C}$ adalah radikal hidroksil $\left(\mathrm{OH}^{\mathbf{0}}\right)$, radikal hydroperoxyl $\left(\mathrm{HO}_{2}{ }^{\mathrm{O}}\right)$, radikal superoksid $\left(\mathrm{O}_{2}\right)$, radikal alkoksil $\left(\mathrm{RO}^{\circ}\right)$, radikal peroxyl $\left(\mathrm{RO}_{2}{ }^{-}\right)$, hydrogen peroksida $\left(\mathrm{H}_{2} \mathrm{O}_{2}\right)$, radikal peroxynitrite, dan radikal nitrit oksid (Baynes, 2005). Reaksi-reaksi asam askorbat dengan radikal bebasantara lain:

Askorbat $+\mathrm{OHsemidehidreskat}$ radikal $+\mathrm{H}_{2} \mathrm{O}$

Askorbat $+\mathrm{O}_{2}$ dehidrostot $+\mathrm{H}_{2} \mathrm{O}_{2}$ Askorbat $+\mathrm{H}_{2} \mathrm{O}_{2}$ de bat + $2 \mathrm{H}_{2} \mathrm{O}$

Vitamin C mudah teroksidasi jika terkena udara dan proses ini dipercepat oleh panas, sinar, alkali, enzim, oksidator, serta katalis tembaga $(\mathrm{Cu})$ dan besi (Fe). Halini karena vitamin $\mathrm{C}$ bersifat tidak stabil,mudah teroksidasi jika terkena udara (oksigen)dan proses ini dapat dipercepat oleh panas (Martin, 1981). Vitamin C mudahteroksidasi karena senyawanya mengandunggugus fungsi hidroksi $(\mathrm{OH})$ yang sangat reaktif, dengan adanya oksidator gugus hidroksiakan teroksidasi menjadi gugus karbonil.Proses Oksidasi akan terhambat bila vitaminC berada dalam keadaan sangat asam ataupada suhu rendah. Vitamin C cukup stabildalam keadaan kering (Winarno, 1988).

Beberapa manfaat fungsional vitamin $\mathrm{C}$ adalah: melawan infeksi dan memperkuat sistem kekebalan tubuh, mencegah arteriosklerosis, agen antivirus yang efektif, Meningkatkan penyerapan kalsium dan zat besi, 
membantu dalam sekresi kelenjar adrenal, dibutuhkan untuk kesehatan gigi dan gusi, melawan radikal bebas karena sifat anti-oksidan, memperbaiki dan memelihara jaringan, berperan penting dalam sintesis kolagen dan memperkuat ligamen, tulang dan pembuluh darah, terlibat dalam proses detoksifikasi yang terjadi di berbagai organ dan jaringan.

Mekanisme kerja asam askorbat (vitamin C) dalam banyak aktivitasnya masih belum jelas, tetapi proses dibawah ini membutuhkan asam askorbat : (1) Hidroksilasi prolin dalam sintesis kolagen. (2) Proses penguraian tiroksin, oksidasi P-hidroksifenilpiruvat menjadi homogentisat memerlukan vitamin $\mathrm{C}$ yang mempertahankan keadaan tereduksi pada ion tembaga yang diperlukan untuk memberikan aktivitas maksimal. (3) Sintesis epinefrin dan tirosin pada tahap dopamine-hidroksilase. Pembentukan asam empedu pada tahap awal 7-alfa-hidroksilase. (5) Korteks adrenal mengandung sejumlah besar vitamin $\mathrm{C}$ yang dengan cepat akan terpakai habis kalau kelenjar tersebut dirangsang oleh hormon adrenokortikotropik. (6) Penyerapan besidigalakkan secara bermakna oleh adanya vitamin C. (7) Asam askorbat dapat bertindak sebagai antioksidan umum yang larut dalam air dan dapat menghambat pembentukan nitrosamin dalam proses pencernaan.

\section{SIMPULAN}

Dari hasil penelitian dan pembahasan dapat disimpulkan bahwa : kandungan vitamin $\mathrm{C}$ dalam mangga kweni rata-rata adalah $3.48 \mathrm{~g} / 100 \mathrm{~g}$.

\section{SARAN}

Mengingat begitu pentingnya vitamin $\mathrm{C}$ bagi tubuh manusia, disarankan untuk mengkonsumsi mangga kweni sabagai salah satu buah yang mengandung vitamin $\mathrm{C}$ cukup tingggi guna memenuhi kebutuhan vitamin $\mathrm{C}$ harian bagi tubuh.

\section{DAFTAR PUSTAKA}

Baynes, J.W. 2005. Oxygen and Life. In: J.W., Baynes, M.H.,Dominiczak

(Eds.):Medical Biochemistry ${ }^{2 n d}$ ed, ElsevierMosby, Philadelphia :500-503.

Budiman,

$\mathrm{H}$. 2003. Nutrisipadausialanjut.Majalah Kedokteran Atmajaya. 2(1): 51-58.

Godam. 2006. Pengertian dan Definisi Vitamin-Fungsi, Guna, Sumber, Akibat Kekurangan, Macam dan Jenis Vitamin.

Harper, J.L. 1986. Pangan, Gizi, dan Pertanian. UnversitasIndonesia, Jakarta.

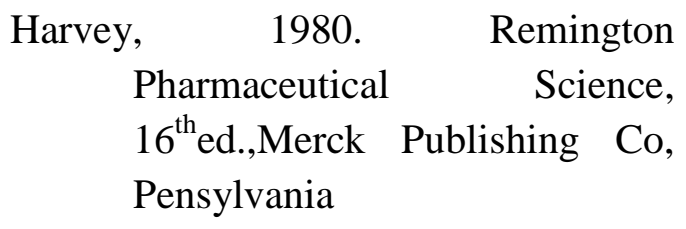

Kooter, I.M. 2004. Inventory of Biomarker for oxidative stress. 
RIVM report within the frame work Project, Bilthoven.

Martin, D.W. 1981. Harper's Review of Biochemistry. $\quad 18^{\text {thed,Los }}$ Altos,California 94022, Lange Medsical Publicatins

Murray R.K, Granner DK, Mayes PA, and Rodwell VW. 1996. Harper's Biochemistry 24 ed.Lange Medical Book USA.

Naidu, K.A. 2003 Vitamin C in human health and disease is still a mystery ? An overview. Nutrition Journal 2003, 2:7

Narins, D.M.C. 1996. Vitamin Dalam Krause's Food, Nutrition and Diet Therapy. Mahlan, L.K, hal 110-114.

Schetman, G. 1989. The Influence of Smoking on Vitamin C Status In Adult. Am. J. Public Health. 79,158-162.

Taylor, A. 1993. Relationships Between Nutrition and Oxidation. J. Am.Coll. Nutr. 12, 138-146.

Wardani, L.A. 2012. Validasi Metode Analisis dan Penentuan Kadar Vitamin C Pada Minuman Buah Kemasan Dengan Spektrofotometri UV-Visibel. FMIPA. Depok.

Winarno, F.G. 1988.Kimia Pangan dan Gizi, Gramedia, Jakarta. 